\title{
PERANCANGAN DESAIN MATA UANG KERTAS RUPIAH SEBAGAI KASUS WACANA REDENOMINASI
}

\author{
Suprayitno \\ Visual Communication Design, School of Design, BINUS University \\ Jln. K.H. Syahdan No. 9, Palmerah, Jakarta Barat 11480 \\ praysutoyo@yahoo.com
}

\begin{abstract}
According to Bank Indonesia, the currency redenomination is simplification by reducing the three-digit number zero, without reducing its value. Fundamental changes in the nominal rate of writing, become very urgent in terms of design drafting new bills. The process and method of creating the work is qualitative, ie, empirical studies of cultural phenomena in the creation of this work aimed at deepening the validity of the data, the researchers involved in the search for the data directly in the field. The way it can play a significant role in revealing and unravel the problem, in order to create connectivity in the creation of the work needs to be focused on the core message. The findings are contributions of renewable and creative solutions in the manufacture of paper currency design planning of Rupiahs, including the proposed vertical format that has never been applied to the design of paper currency of Rupiahs. Then the proposed implementation of security features barcode, which has advantages and superiority in facilitating the detection of counterfeit banknotes, will make digital counting faster and more accurate than manual.
\end{abstract}

Keywords: redenomination, the method for creating, designing the rupiah banknotes

\begin{abstract}
ABSTRAK
Menurut Bank Indonesia redenominasi adalah penyederhanaan mata uang dengan mengurangi digit tiga angka nol, tanpa mengurangi nilainya. Perubahan mendasar pada penulisan angka nominal tersebut, menjadi sangat mendesak dalam hal pembuatan rancangan desain uang kertas baru. Proses dan metode penciptaan karya bersifat kualitatif, yakni kajian fenomena budaya empirik dalam penciptaan karya ini dimaksudkan pada pendalaman validitas data, peneliti melibatkan diri dalam upaya pencarian data secara langsung di lapangan. Cara tersebut dapat berperan secara signifikan dalam mengungkapkan serta mengurai masalah, agar tercipta koneksitas dalam penciptaan karya perlu ditekankan pada inti pesannya. Temuan terbarukan serta kontribusinya adalah berupa solusi kreatif dalam membuat perancangan desain mata uang kertas rupiah, diantaranya adalah usulan format vertikal yang belum pernah diterapkan pada desain uang kertas rupiah. Kemudian usulan penerapan fitur pengamanan barcode, yang memiliki kelebihan dan keunggulan dalam mempermudah mendeteksi uang kertas palsu, akan membuat penghitungan secara digital akan lebih cepat dan akurat daripada manual.
\end{abstract}

Kata kunci: redenominasi, metode penciptaan, perancangan desain mata uang kertas rupiah 


\section{PENDAHULUAN}

Makna redenominasi menurut Gubernur Bank Indonesia adalah penyederhanaan mata uang dengan mengurangi digit angka nol, tanpa mengurangi nilainya. Pada masa transisi akan ada dua jenis mata uang, yakni pecahan lama dan pecahan baru, dengan nilai yang sama. Semisal, pecahan Rp 50.000 sebelum redenominasi dan Rp 50 setelah redenominasi bernilai sama. Pencatatan pada perbankan juga akan mulai dalam nominal rupiah baru. Jika nasabah mengambil uang melalui kasir atau ATM uang yang akan keluar adalah rupiah baru. Bank tetap menerima rupiah lama yang disetor nasabah. Setelah tahap transisi berakhir, proses redenominasi akan masuk tahap phasing out yang berlaku mulai 2019 hingga 2022, seluruh transaksi dilakukan dengan perubahan wajah desain uang baru menggantikan uang masa transisi. Sementara uang rupiah lama dinyatakan dicabut dan ditarik dari peredaran. Sehingga pada tahapan ini, tidak ada lagi penyebutan rupiah lama dan baru. Namun, masyarakat masih diberikan tenggat waktu yang cukup untuk melakukan penukaran, yaitu selama 10 tahun setelah tanggal pencabutan. (bisniskeuangan.kompas.com)

Ide perancangan desain mata uang kertas rupiah ini, selain terkait dengan wacana pelaksanaan kebijakan moneter 'redenominasi', yang akan diterapkan oleh Pemerintah melalui Bank Indonesia, untuk menerbitkan uang sebagai alat pembayaran yang sah, serta terinspirasi dari momentum pengakuan atas warisan budaya tak benda yang telah diakui oleh badan dunia UNESCO. Hal tersebut bertujuan untuk meningkatkan kesadaran tentang warisan budaya tak benda untuk mempromosikan serta melindungi karya agung melalui medium uang kertas rupiah.

Perancangan desain uang kertas rupiah ini adalah untuk memberikan alternatif solusi perancangan visual desain uang kertas rupiah dengan unsur nilai kebaruan desain yang inovatif kepada Bank Indonesia. Tujuannya, antara lain, (1) Membuat perancangan desain uang kertas yang baru di akhir masa transisi redenominasi, dengan menghapus tiga angka nol. (2) Membuat perancangan desain uang kertas yang baru dengan memanfaatkan momentum Intangible Cultural Heritage UNESCO, sebagai visualisasi utama pada lembar uang kertas. Seperti Wayang, Keris, Batik, Angklung, Tari Saman, dan Noken tas anyaman Papua. Visualisasi tersebut, telah ikut melindungi serta menjaga klaim/pengakuan atas Hak Atas Kekayaan Intelektual (HAKI) oleh negara lain.

“Dewasa ini bidang kegiatan desain grafis semakin luas, mencakup semua aspek komunikasi visual melalui penciptaan logo (trade mark), perencanaan dan pembuatan buku berikut wajah sampul, ilustrasi dan tipografinya, sampul CD (Compact-Disk), perencanaan wajah kalender, grafis untuk segala bentuk kemasan, grafis untuk arsitektur, semua keperluan barang cetakan (company profile, stationery kit, greeting card) perusahaan, tipografi judul film dan televisi, poster, benda pos, mata uang, surat kabar, majalah dan sebagainya” (Banindro, 2002)

Penerapan visual momentum Intangible Cultural Heritage UNESCO tersebut sekaligus dapat memperkokoh pernyataan bahwa kekayaan warisan budaya tersebut adalah milik bangsa Indonesia yang wajib dijaga dan dilestarikan. Berdasarkan tujuan tersebut diatas, penulis ingin memberikan kontribusi berupa solusi kreatif dalam membuat perancangan desain mata uang kertas rupiah, yang antara lain adalah usulan format vertikal atau portret. Menurut pengamatan serta hasil observasi, belum pernah ada hasil rancangan desain mata uang kertas rupiah dengan format vertikal, umumnya desain uang kertas rupiah masih menggunakan format horizontal. Kemudian usulan penggunaan fitur pengamanan barcode yang memiliki kelebihan serta keunggulan dalam mendeteksi uang kertas menjadi lebih mudah, penghitungan secara digital juga akan lebih cepat dan akurat daripada manual, serta lebih menjamin keaslian dan keabsahan uang kertas tersebut.

Manfaat penggunaan momentum Intangible Cultural Heritage UNESCO antara lain (1) Untuk Masyarakat, memberikan unsur edukasi kepada generasi muda khususnya, agar dapat lebih mengenal serta mencintai warisan budaya bangsanya, untuk kemudian dapat menjaga serta melestarikannya. 
Sehingga memberikan kebanggaan tersendiri dengan adanya penerapan unsur budaya tersebut pada medium uang kertas rupiah terkait dengan pelaksanaan redenominasi. (2) Untuk Lembaga Pemerintah dalam hal ini Bank Indonesia, membantu memberikan alternatif solusi kreatif second opinion terhadap permasalahan perancangan desain mata uang kertas rupiah redenominasi. (3) Untuk Lembaga Pendidikan, sebagai bahan referensi dunia pendidikan mengenai perancangan desain uang kertas rupiah yang memiliki ciri khas momentum Intangible Cultural Heritage UNESCO.

\section{METODE}

Proses dan metode penciptaan karya lebih bersifat kualitatif, yakni kajian fenomena budaya empirik dalam penciptaan karya ini dimaksudkan pada pendalaman faliditas data, peneliti melibatkan diri dalam upaya pencarian data secara langsung di lapangan. Jenis penelitian metode kualitatif ini berlandaskan pada filsafat kebenaran sesuai dengan hakekat objek, digunakan untuk meneliti pada kondisi objek yang alamiah, di mana peneliti sebagai instrumen kunci dan hasil penelitian lebih menekankan makna daripada generalisasi. (Sugiyono, 2008). Sehingga cara tersebut dapat membantu secara signifikan dalam mengungkap serta mengurai masalah, agar tercipta koneksitas dalam penciptaan karya.

Rancangan atau desain metode kualitatif ini dapat membantu serta melengkapi data yang diperoleh akan lebih akurat, lebih mendalam, kredibel, dan bermakna, sehingga tujuan penelitian dapat dicapai. Desain metode kualitatif ini dibagi dalam empat tahap, yaitu perencanaan, pelaksanaan, analisis data, dan evaluasi (Moleong, 2002).

\section{Perencanaan}

Kegiatan yang dilakukan dalam tahap ini adalah sebagai berikut: analisis standar bentuk fisik uang kertas yang pernah beredar maupun proses cetak uang kertas serta pengamanannya (security printing), penyusunan rancangan penelitian, penetapan tempat penelitian, penyusunan instrumen penelitian dan perencanaan perancangan desain mata uang kertas rupiah.

\section{Pelaksanaan}

Pada tahap ini peneliti sebagai pelaksana penelitian sekaligus sebagai human instrument mencari informasi data, melalui literatur dan juga wawancara mendalam dengan bapak Subandrio sebagai Direktur Produksi Peruri. Selain itu peneliti juga menganalisis serta mengobservasi uang kertas dari bentuk, warna ukuran maupun fitur pengamanan (security printing) secara mendalam.

\section{Analisis Data}

Analisis data dilakukan setelah peneliti mendapatkan data berbagai sumber baik dari literatur, observasi terhadap berbagai jenis mata uang kertas maupun melakukan wawancara secara langsung.

\section{Evaluasi}

Setelah semua data yang terkumpul dari berbagai sumber tersebut telah dianalisis, kemudian dievaluasi sehingga dapat diketahui kebutuhan apa saja yang harus disiapkan serta dilengkapi dalam perancangan desain mata uang kertas rupiah tersebut. 


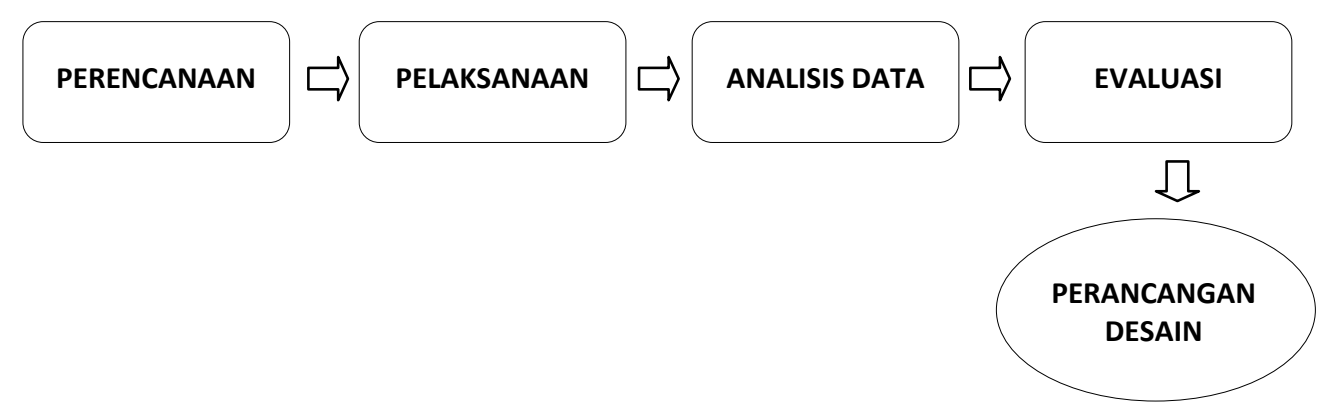

Gambar 1 Alur tahapan metode kualitatif

\section{HASIL DAN PEMBAHASAN}

Desain mata uang kertas rupiah ini dalam proses perancangannya merupakan pengembangan dari bentuk-bentuk desain mata uang kertas yang sudah pernah dicetak dan beredar pada kurun waktu tertentu, baik yang masih berlaku maupun yang sudah tidak berlaku. Sebagai contoh gaya visual desain mata uang kertas 50 Gulden di rancang pada tahun 1982, dan 250 Gulden tahun 1986 adalah hasil rancangan desainer R.E.D. Oxenaar dan J. J. Kruit. Pendekatan desain yang digunakan berbeda dari desain-desain mata uang sebelumnya, sehingga di dalam buku Megg's History of Graphic Design (Megg 2006), memberikan apresiasinya, bahwa desain mata uang kertas ini adalah desain yang inspiratif dan memberikan nilai kebaruan. Desain mata uang tidak selalu menggunakan style atau gaya klasik. Oleh karena itu desain tersebut menjadi salah satu sumber inspirasi.
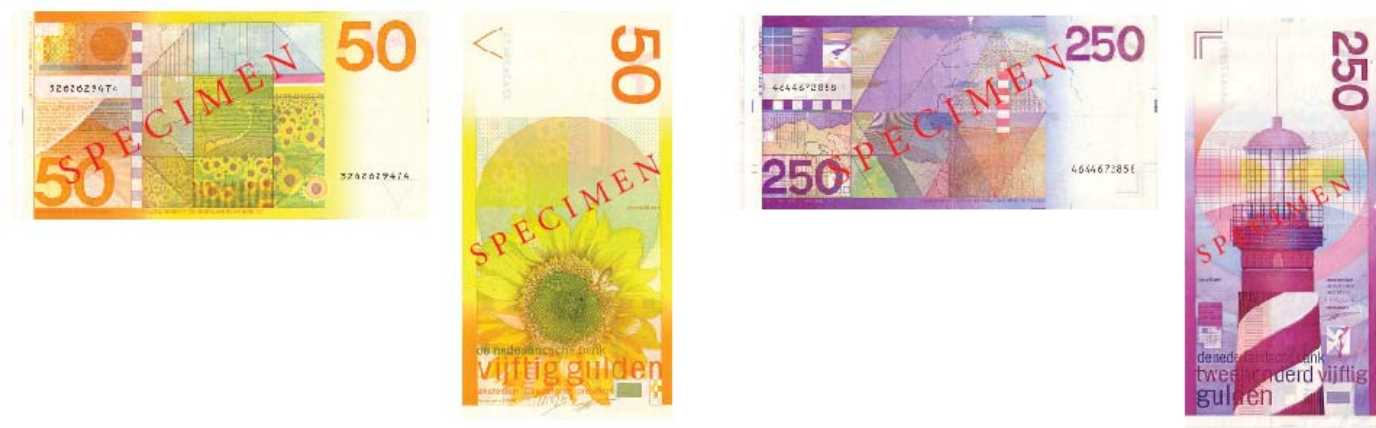

Gambar 2 Desain mata uang kertas Gulden Netherland

Sumber: Megg's History of Graphic Design, 2006:460

Penggunaan fitur pengamanan barcode pada uang kertas ternyata masih belum banyak digunakan, meskipun kecenderungan untuk menggunakan barcode sebagai salah satu tambahan fitur ini ada. Sebagai contoh desain mata uang Belanda yaitu mata uang kertas Gulden Belanda Emisi tahun 1992 telah menggunakan fitur barcode bahkan negara Lebanon Emisi tahun 1998 juga telah melengkapi fitur pengamanannya dengan 'barcode'. Fitur pengamanan barcode setidaknya dapat meminimalisir tindak kejahatan pemalsuan yang masih tetap ada. 

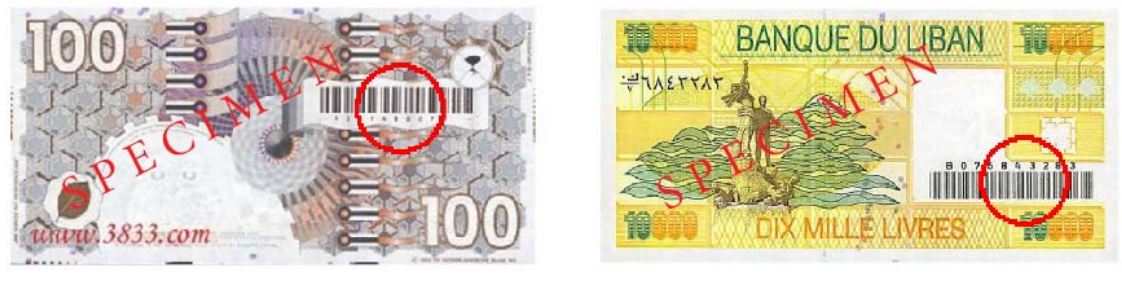

Gambar 3 Mata uang Gulden Netherland \& Lebanon dengan fitur 'barcode' Sumber: 3833.com \& banknotes.com

Desain uang kertas rupiah Indonesia juga pernah mengambil relief sebagai tema visual pada uang lama nominal 10.000 rupiah emisi tahun 1975. Menerapkan motif dan gambar yang sangat menarik berupa relief candi Borobudur pada bagian depan dan Barong pada bagian belakang sehingga sangat digemari oleh kolektor lokal maupun mancanegara karena keunikannya.
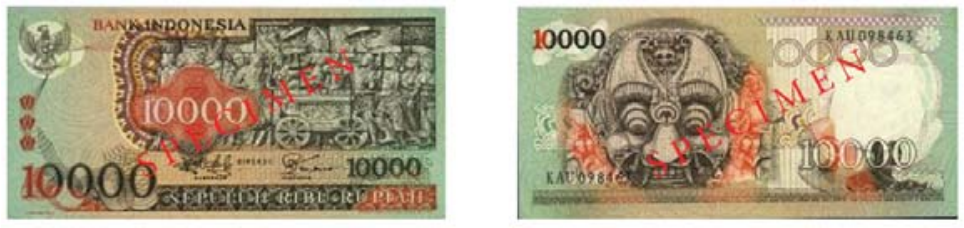

Gambar 4 Contoh uang kertas 10.000 rupiah, emisi tahun 1975 Sumber: uangkuno.com

Referensi visual uang kertas tersebut banyak memiliki kelebihan dalam masing-masing desainnya, antara lain: (1) Gaya desain mata uang kertas memiliki karakter, sebagai ikon dari suatu negara yang berdaulat. "A rare aesthetic attainment and functional practicality enabled currency to contribute a sense of national identity." (Megg, 2006). (2) Pola maupun format yang tidak selalu horizontal, karena dalam proses transaksi, menyerahkan uang dapat dilakukan dalam posisi vertikal. Oleh karena itu desain mata uang kertas rupiah dapat di rancang dengan format vertikal. (3) Usulan fitur pengamanan tambahan barcode memiliki keunggulan dalam bertransaksi, lebih mempercepat dan mempermudah, yang layak untuk dicoba diaplikasikan, meskipun harus diantisipasi dalam proses persiapan prasarana pendukungnya. (4) Desain dengan keunikan yang partikular, yakni mempertahankan unsur local genius, dapat menjadi kekuatan desain tersendiri.

Menurut Gustami (2007) persoalan yang timbul adalah bagaimana membawa nilai tradisi ke dalam kehidupan global, menyangkut visi dan misi pengembangan kesenian kita yang ingin mentransformasikan nilai lama ke dalam kehidupan baru. Hasrat itu tentu bergayut dengan spirit, ruh dan jiwa zamannya. Desain Komunikasi Visual (DKV) merupakan salah satu bagian dari seni terapan yang mempelajari perencanaan perancangan dari beragam bentuk informasi komunikasi visual. Proses kreatif dimulai dari mengenali dan menemukan permasalahan, mencari data verbal dan visual, menyusun konsep kreatif yang berpijak pada target sasaran, hingga penentuan visualisasi final perancangan desain visual, guna mendukung tercapainya suatu komunikasi verbal maupun visual yang tepat, fungsional, persuasif, arstistik dan komunikatif. Desain dalam pemahaman saat ini adalah desain merupakan produk olah pikir yang dilandasi oleh ilmu pengetahuan, rasional dan pragmatis (Tinarbuko, 2009). 
Proses perancangan komunikasi visual hendaknya dipahami secara luas. Sehingga pendekatan teori secara multidisiplin tentu akan dapat lebih memperkaya serta mempertajam hasil dari membedah suatu permasalahan desain, untuk mendapatkan solusi kreatif yang berbeda dan lebih baik. Identifikasi teori-teori, prinsip-prinsip serta teknik-teknik yang akan membantu dalam pemecahan masalahmasalah visual tersebut, seperti: (1) Teori Komunikasi, membantu dalam menyusun masalah yang dihadapi dalam hubungannya dengan pesan yang dimaksud dengan khalayak sasaran. (2) Teori Semiotika Visual, membantu dalam menerangkan hubungan antara tanda dan pertaliannya, sebagai sebuah informasi yang komunikatif, adanya tanda mampu menggantikan sesuatu yang dapat dipikirkan, ataupun dibayangkan. (3) Teori dasar desain grafis, adalah prinsip olah visual dan estetika bentuk yang dapat membantu membangun hubungan unsur-unsur visual titik, garis, bidang, dan juga kualitas intrinsik seperti ukuran, proporsi, tekstur, warna, dst. dalam proses penciptaan perancangan yang diinginkan.

Karya momentum pengakuan UNESCO terhadap warisan budaya bangsa Indonesia, diangkat sebagai tema visualisasi perancangan desain mata uang kertas rupiah, adalah wujud dari kepedulian untuk ikut melestarikannya. Wajah baru visualisasi mata uang kertas rupiah ini, diharapkan menjadi suatu bentuk representasi dari sebuah misi budaya bangsa melalui warisan budaya khas Indonesia. Mengutip pendapat Banindro, bahwa:

"Uang kertas dapat digunakan sebagai alat untuk menyampaikan informasi yang bersumber dari pemerintah, atau negara kepada rakyatnya. Pada setiap mata uang kertas baru yang beredar, desain grafis mata uang kertas Indonesia membawa inti pesan-pesan berupa isu politik, sosial, ekonomi dan kebudayaan sehingga informasi kepada rakyat sebagai sasaran pesan sampai kepada objeknya..” (Banindro, 2008)

Setiap hasil karya grafis atau desain komunikasi visual, tentu memiliki unsur-unsur elemen layout dalam sebuah karya. Di dalam sebuah layout khususnya desain mata uang kertas memiliki banyak elemen yang memiliki peran yang berbeda-beda dalam membangun keseluruhan pengorganisasian elemen-elemen guna mencapai tujuan pesan yang ingin disampaikannya. Guna mengoptimalkan hasil rancangan desain, maka perlu mengetahui peran masing-masing elemen tersebut. Elemen-elemen layout dapat di klasifikasikan menjadi tiga (Rustan, 2009), yakni:

\section{Elemen Visual}

Elemen Visual merupakan kelompok elemen bukan teks, yakni seluruh elemen visual yang terlihat dalam sebuah layout khususnya desain mata uang kertas, antara lain: (a) Artworks, adalah segala jenis karya seni bukan fotografi baik itu berupa ilustrasi dengan berbagai teknik, sketsa digital atau manual, maupun karikatur. Jadi artworks adalah visualisasi suatu pesan atau informasi pada uang kertas umumnya menggunakan ilustrasi sebagai elemen visual utamanya. Ada juga visualisasinya dengan pendekatan teknik dan gaya visual yang lebih moderen seperti gaya dekoratif maupun dengan teknik modifikasi secara digital. (b) Pada umumnya desain uang kertas menggunakan ilustrasi sebagai pilihan. "...illustration need to have knowledge, understanding and insight regarding the context within they are working...” (Male, 2007:11), jadi sebuah ilustrasi harus memiliki pengetahuan, pemahaman serta insight yang kontekstual mengenai apa yang ingin disampaikan menjadi sebuah pesan agar tampilan gambar ilustrasi tersebut dapat bekerja dengan baik dan tepat. Sebagai visual utama, maupun elemen visual pendukung yang lainnya. (c) Elemen hias adalah bentuk dasar motif yang biasanya akan menjadi pola yang diulang, dan sangat khas sebagai representasi budaya pada era tertentu. Elemen hias nusantara dapat ditemukan pada motif batik, tenunan, anyaman, tembikar, ukiran kayu, atau pada pahatan batu. Menurut Toekio (1987), ragam hias untuk sesuatu benda pada dasarnya merupakan sebuah pedandan (makeup) yang diterapkan guna mendapatkan keindahan atau kemolekan yang dipadukan. Ragam hias tersebut berperan sebagai media untuk mempercantik atau menganggunkan suatu karya seni. 


\section{Elemen Teks}

Elemen Teks adalah seluruh kelompok elemen yang mengandung unsur huruf dan tipografi dalam sebuah layout karya desain. Sihombing (2003) mengungkapkan bahwa melalui kandungan nilai fungsional dan nilai estetikanya huruf berpotensi untuk menerjemahkan atmosfir-atmosfir yang tersirat dalam sebuah komunikasi verbal yang dituangkan melalui abstraksi bentuk-bentuk visual. Hal yang harus diperhatikan adalah: (a) Legibility, yakni kualitas huruf untuk mudah dibaca. (b) Readibility, yakni pemilihan huruf yang tepat agar mudah dibaca. (c) Visibility, yakni huruf yang mudah terlihat.

\section{Elemen Maya / Virtual Elements}

Elemen Maya / Virtual Elements adalah elemen layout yang tidak tampak, namun merupakan fondasi sebagai kerangka acuan yang memiliki fungsi sebagai pedoman dalam penempatan seluruh elemen layout dalam sebuah bidang. Dua elemen maya / virtual element, yakni margin dan grid system, kerangka bidang kerja sebuah layout desain grafis atau desain komunikasi visual, sebagai berikut: (a) Margin, adalah batas atau jarak antar pinggir kertas atau bidang dengan ruang yang akan diletakkan elemen-elemen layout. (b) Grid System, tujuannya adalah untuk mempermudah dalam menentukan dimana harus meletakkan elemen layout serta mempertahankan konsistensi serta kesatuan layout. Umumnya desain uang ketas dibuat serial, dengan dibedakan nominal maupun elemen visual utamanya, namun secara keseluruhan tampak sintaktik dan unity.

Prinsip dasar layout adalah prinsip dasar desain komunikasi visual. Sebagai seorang desainer dalam merancang sebuah karya desain harus memiliki tugas dan tanggungjawab untuk menyampaikan pesan-pesan kepada target audience melalui karya desainnya. Pesan visual harus memiliki keunikan tersendiri sehingga harus kreatif, komunikatif, unik, efektif, efisien dan sekaligus memiliki unsur keindahan.

Metode proses perancangan, menurut Hendriyana (2009), pengertian metodologi dan metode adalah suatu hal yang berbeda. Metode berasal dari kata methodos yang berarti cara atau jalan, cara kerja untuk memperoleh sebanyak mungkin gejala atau untuk memahami suatu objek penelitian. Metode adalah teknik riset atau alat yang dipergunakan untuk mengumpulkan data. Pengertian tersebut maka timbul kata metode wawancara, metode observasi, metode empirik, metode deskripsi dan lain sebagainya. Metodologi adalah falsafah dalam proses riset yang membahas aturan-aturan tertentu sebagai prosedur intelektual dalam komunitas ilmiah.

Proses dan metode penciptaan karya lebih bersifat kualitatif, yakni bersifat empirik dalam penciptaan karya ini dimaksudkan pada pendalaman validitas data, peneliti melibatkan diri dalam upaya pencarian data secara langsung di lapangan. Cara tersebut dapat berperan dalam mengungkapkan serta mengurai masalah, agar tercipta koneksitas dalam penciptaan karya. Menurut Marianto (2011), kata 'mengamati' sama dengan 'to observe' kata bendanya 'pengamatan' dengan padanan kata 'observation', yang artinya: mengamati seseorang, sesuatu, atau situasi, dengan seksama untuk memelajarinya secara lebih cermat sampai detil-detilnya. Observasi sering dikaitkan dengan kreativitas, sehingga begitu pentingnya observasi dalam olah kreatif seorang kreator.

Salah satu program UNESCO (Representative of the Intangible Cultural Heritage of Humanity) tujuannya adalah menjamin visibilitas yang lebih baik bagi warisan budaya tak-benda dan kesadaran akan nilai pentingnya melestarikan berbagai kekayaan lisan dan tak-benda umat manusia di seluruh dunia. Momentum pengakuan badan dunia yang diwakili UNESCO terhadap beberapa warisan budaya tak-benda seperti Wayang, Keris, Batik, Angklung, Tari Saman, dan terakhir Noken tas anyaman Papua, diharapkan akan menjadi misi budaya bangsa, baik dalam lingkup nasional maupun internasional. (Sumber: unesco.co.org) 
"Setelah melewati perjuangan yang panjang dan 'terjal', melalui proposal, seminar, serta konferensi internasional akhirnya pada 25 November 2005 (United Nation's Educational, Scientific and Cultural Organization) mendeklarasikan bahwa keris Indonesia adalah Masterpiece of the Oral and Intangible Herritage of Humanity. Pengakuan ini secara simbolis sungguh luar biasa dan penting. Konsekuensinya, Indonesia harus melestarikan dan mengembangkan warisan kemanusiaan ini.” (Marianto, 2011)

Proses kreatif merujuk pada meningkatnya keterbukaan terhadap pengalaman, pengamatan, kemauan berimprovisasi serta kemampuan beradaptasi dengan cepat terhadap suatu situasi, dan mampu mengobservasi kepada hal-hal yang tidak terbayangkan sebelumnya. Tahapan proses kreatif diklasifikasikan, menjadi: (1) Tahap preparation, sebagai tahap persiapan melalui pengumpulan informasi dari beragam gagasan yang tumbuh untuk mencari solusi guna memecahkan masalah, atau menset langkah solusi kreatif. (2) Tahap incubation adalah masa pencarian hingga penemuan pemecahan masalah secara kreatif berada pada tingkat ambang bawah sadar. (3) Tahap illumination adalah saat mendapatkan sebuah pencerahan, solusi kreatif bisa saja muncul tiba-tiba, hingga dapat menjadi suatu insight. (4) Tahap verification merupakan tahapan akhir sebagai pembuktian setelah mendapatkan pencerahan sebagai solusi nyata sekaligus jawaban.

Karya akhir dari perancangan ini adalah model atau dummy rancangan serial desain mata uang kertas rupiah, dimulai dengan sketsa thumbnail hingga sketsa digital komprehensif untuk dikembangkan, kemudian dipilih satu sebagai acuan desain uang kertas rupiah. Proses perwujudan perancangan desain uang kertas rupiah ini, setelah melalui sketsa layout awal kemudian dilanjutkan dengan sketsa komprehensif layout secara digital sebagai bahan rujukan untuk menjadi acuan serial desain secara keseluruhan.
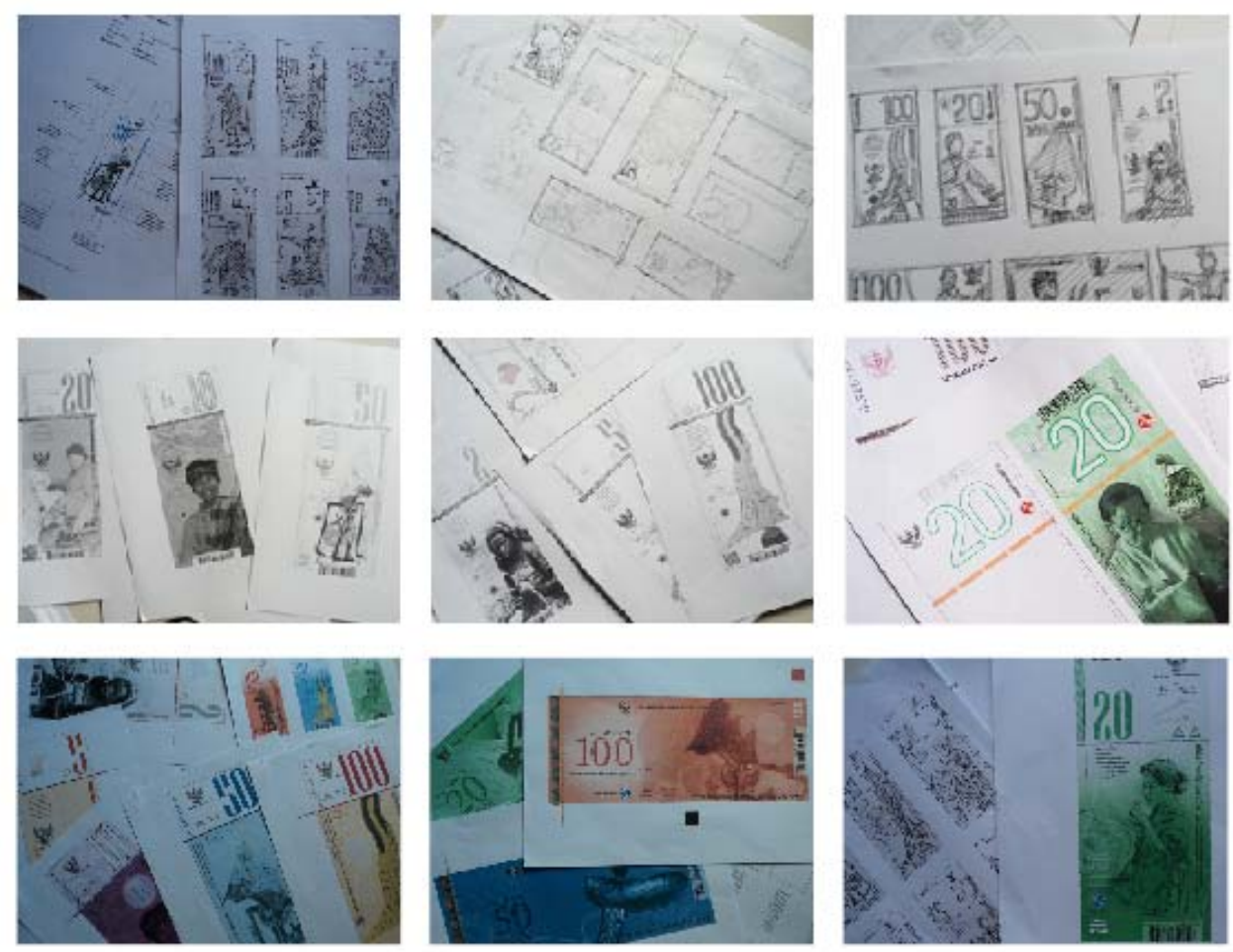

Gambar 5 Sketsa proses perancangan desain uang kertas rupiah 


\section{HASIL PERANCANGAN}

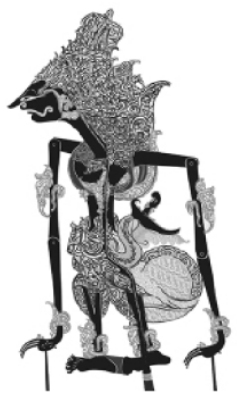

Sketsa Prabu Kresna
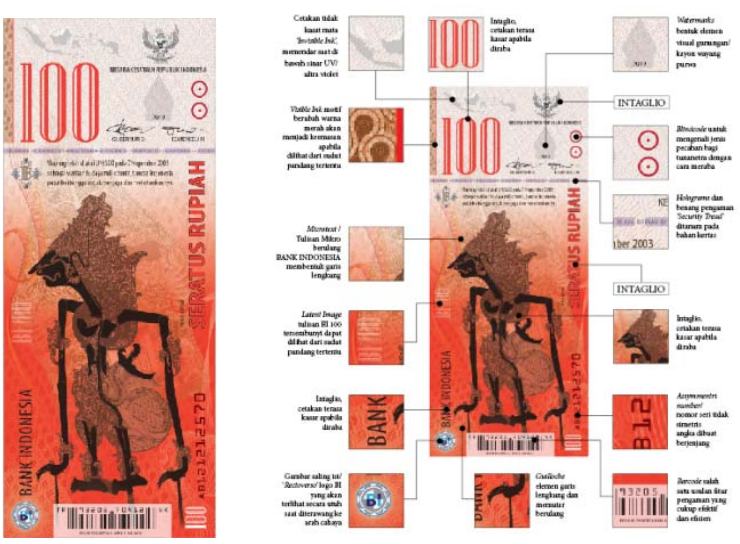

Desain dan anatomi uang kertas 100 rupiah

Gambar 6 Perancangan desain uang kertas 100 rupiah, visual: Suprayitno

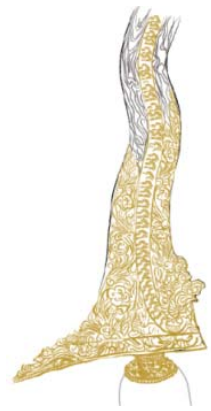

Sketsa Keris Nagasasra
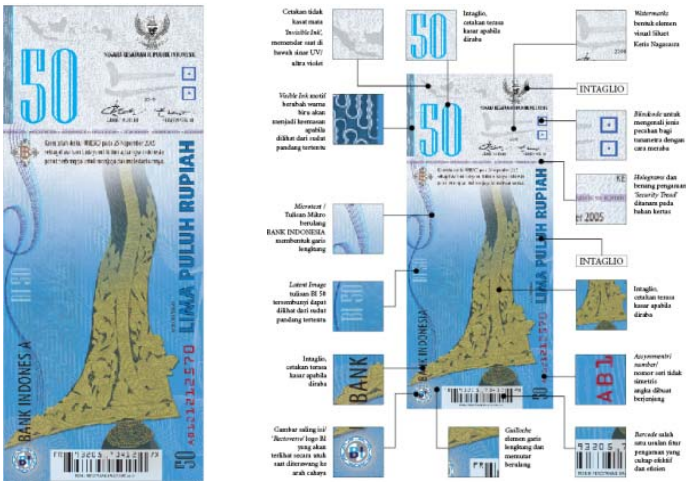

Desain dan anatomi uang kertas 50 rupiah

Gambar 7 Perancangan desain uang kertas 50 rupiah, visual: Suprayitno

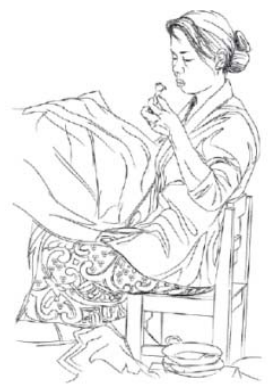

Sketsa Perajin Batik
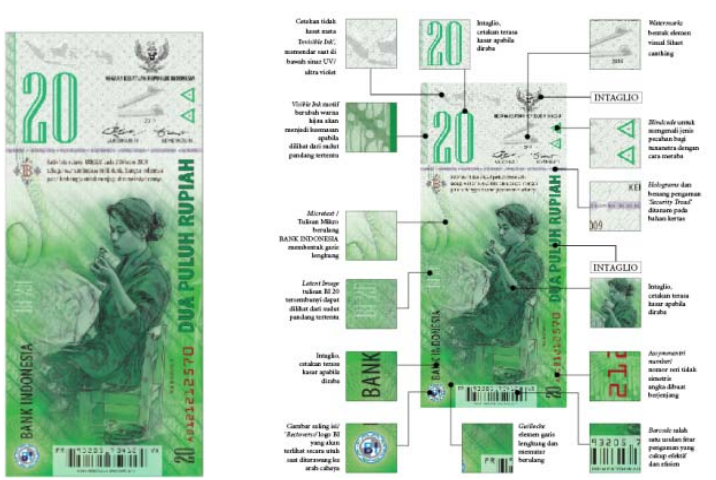

Desain dan anatomi uang kertas 20 rupiah

Gambar 8 Perancangan desain uang kertas 20 rupiah, visual: Suprayitno 


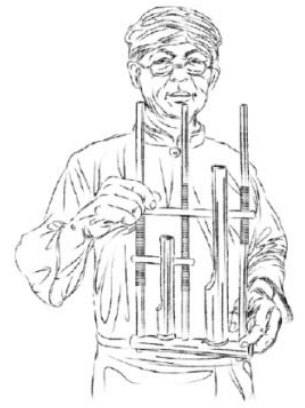

Sketsa Perajin Angklung
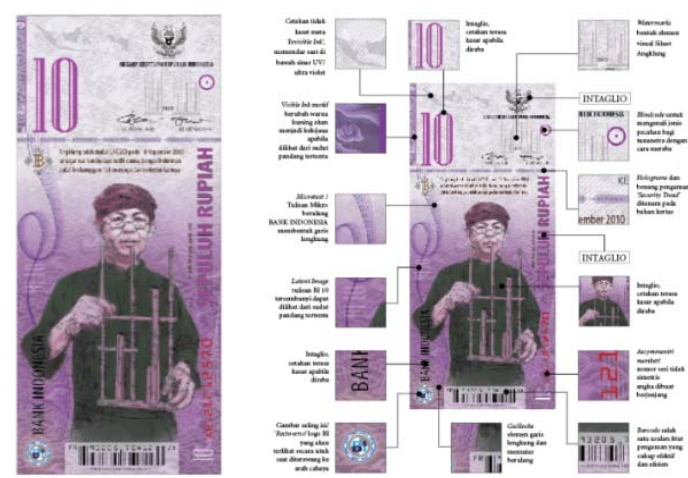

Desain dan anatomi uang kertas 10 rupiah

Gambar 9 Perancangan desain uang kertas 2 rupiah, visual: Suprayitno

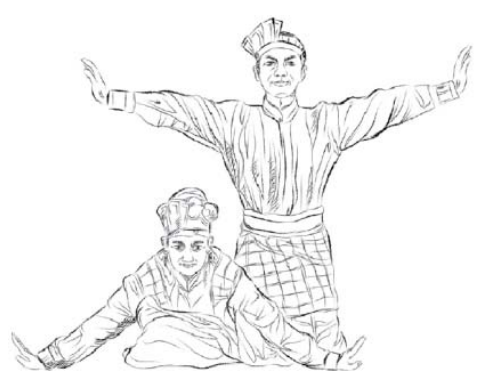

Sketsa Penari Saman Aceh
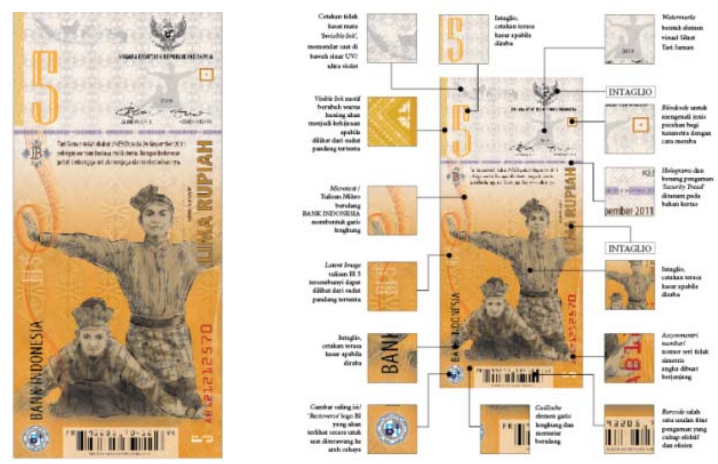

Desain dan anatomi uang kertas 5 rupiah

Gambar 10 Perancangan desain uang kertas 5 rupiah, visual: Suprayitno

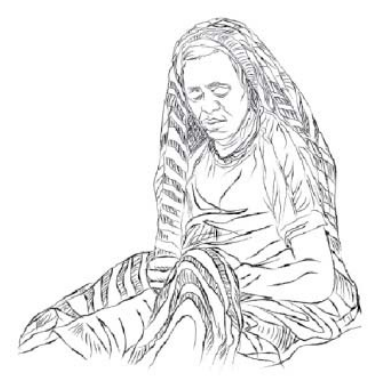

Sketsa Perajin Noken Papua
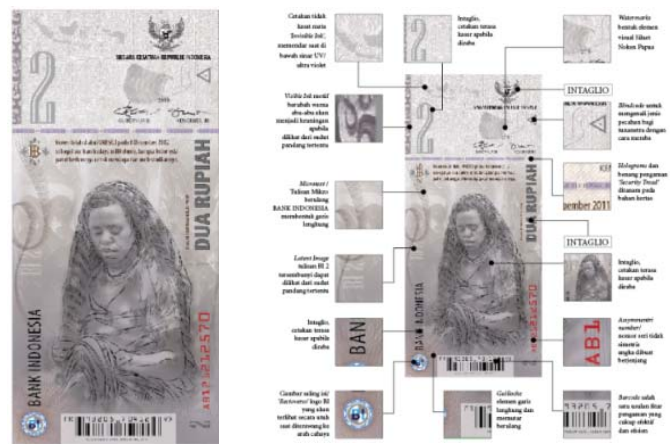

Desain dan anatomi uang kertas 2 rupiah

Gambar 11 Perancangan desain uang kertas 2 rupiah, visual: Suprayitno 


\section{SIMPULAN}

Hasil perancangan desain uang kertas rupiah versi redenominasi ini tentunya memiliki nilai tersendiri yang khas sebagai representasi dari bangsa yang besar dan kaya akan budaya, sehingga selain memberikan unsur edukasi terhadap generasi muda penerus bangsa juga memilki keunikan tersendiri dan eksklusif. Penerapan unsur budaya pada desain uang kertas tersebut memberikan nuansa yang berbeda, karena bangsa Indonesia memiliki puluhan bahkan ratusan kekayaan warisan budaya bangsa yang layak dibanggakan, dijaga dan dilestarikan. Perancangan dengan visualisasi momentum Intangible Cultural Heritage UNESCO tersebut, telah ikut melindungi serta menjaga klaim atau pengakuan Hak Atas Kekayaan Intelektual (HAKI) oleh negara lain. Penerapan visual momentum tersebut sebagai visual utama uang kertas rupiah sekaligus dapat memperkokoh pernyataan bahwa kekayaan warisan budaya tersebut adalah milik bangsa Indonesia yang wajib dijaga dan dilestarikan.

Proses dan metode penciptaan karya lebih bersifat kualitatif, dan empirik dalam penciptaan karya, peneliti melibatkan diri dalam upaya pencarian data secara langsung di lapangan. Metode tersebut dapat membantu mengungkapkan serta mengurai masalah, agar tercipta koneksitas dalam penciptaan karya. Proses kreatifnya dimulai dengan observasi, analisis data, kemudian dirumuskan menjadi sebuah konsep perancangan yang baik dan tepat sesuai dengan tujuan. Pendekatan unsur budaya masih sangatlah luas dan tanpa batas sebagai sumber inspirasi dalam perancangan desain uang kertas sebagai studi penciptaan desain komunkasi visual. Unsur warisan budaya atau local genius merupakan objek yang sangat unik, menarik dan eksklusif, sehingga layak untuk ditindak lanjuti serta dikembangkan sebagai bagian dari pelestarian budaya bangsa. Penulis sangat menyadari dengan keterbatasan waktu, maka hasil karya perancangan desain uang kertas rupiah ini, masih dapat dikembangkan serta dieksplorasi menjadi lebih baik lagi. Penentuan serta pemilihan visualisasi pada perancangan desain uang kertas rupiah dapat bersifat tematik maupun non-tematik menjadi sangat penting untuk dipertimbangkan tingkat kesulitannya, agar dapat meminimalisir kendala teknis sehingga dapat membuat perencaaan menjadi lebih matang, guna mendukung keberhasilan sesuai dengan tujuan.

\section{DAFTAR PUSTAKA}

Banindro, B. S. Juli (2002). Wacana Hak-hak Atas Kekayaan Intelektual dalam Penciptaan Karya Desain Grafis, Jurnal Nirmana, 4(2), Universitas Kristen Petra, Surabaya

Banindro, B. S. Januari (2012). Kajian Ikongrafis Bahasa Rupa Uang Kertas Indonesia Masa Revolusi, Jurnal Dekave, 1(3), PS Disain Komunikasi Visual FSR Yogyakarta, Yogyakarta

Gustami S. P. (2007). Butir-butir Mutiara Estetika Timur, Ide dasar Penciptaan Seni Kriya. Yogyakarta: Prasista

Hendriyana, H. (2009). Metodologi Kajian Artefak Budaya Fisik (Fenomena Visual Bidang Seni). Bandung: Sunan Ambu STSI Press

Male, A. (2007). Illustration: A Theoretical \& Contextual Perspective. London: AVA Publs.

Marianto, M. D. (2011). Menempa Quanta Mengurai Seni. Yogyakarta: BP ISI Yogyakarta

Marianto, M. D. September (2011). Estetika Keris Nasional, Mengingat Kriya Seni, Jurnal ARS/XIV, BP ISI Yogyakarta, Yogyakarta 
Moleong, L. J. (2002). Metodologi Penelitian Kualitatif. Bandung: Remaja Rosdakarya

Rustan, S. (2009). Layout Dasar \& Penerapannya. Jakarta: Kompas Gramedia

Sihombing. D. (2003). Tipografi dalam Desain Grafis, Jakarta: Gramedia Pustaka Utama

Sugiyono. (2008). Metode Penelitian Kuantitatif, Kualitatif dan R\&D. Bandung : Alfabeta

Tinarbuko, S. (2009). Semiotika Komunikasi Visual. Yogyakarta: Jalasutra

Toekio, M. S. (1987), Mengenal Ragam Hias Indonesia, Bandung: Penerbit Angkasa

Saputra, FX L. A. (2013). Meringkas Rupiah, Kompas (Online). Diakses 7 Mei 2013 dari http: //bisniskeuangan.kompas.com/read/2013/01/29/10104098/ Meringkas. Rupiah?

UNESCO ICH. (2008). Representative List of the Intangible Cultural Heritage of Humanity, Criteria Intangible Heritage. Diakses 25 September 2013 dari http://www.unesco.org/culture/ich/index.php?lg =en\&pg = 00311\&topic=mp\&cp=ID 